\title{
HATE SPEECH ACTS: A CASE IN BATU BARA
}

\author{
Rahmadsyah Rangkuti ${ }^{1}$, Andi Pratama², Zulfan ${ }^{3}$ \\ ${ }^{1}$ Department of English, Faculty of Cultural Sciences, University of Sumatera Utara \\ ${ }^{2}$ Department of Arabic, Faculty of Cultural Sciences, University of Sumatera Utara \\ ${ }^{3}$ Department of Linguistics, Faculty of Cultural Sciences, University of Sumatera Utara \\ E-mail: rangkuti@usu.ac.id
}

Received: 02-12-2019

Accepted: 16-12-2019

\begin{abstract}
Hate speech acts that occur in the online realm expressed with words of prejudice and negative feelings are far more dangerous than in the offline realm. Hate speech is a new area in the study of illocutionary speech acts. This new area of speech acts becomes more interesting because every hate speech has various meanings or illocutionary forces based on speaker's intention. This study aims to analyse the classifications and aims of illocutionary acts and illocutionary forces of hate speech contained in two face book group accounts related to Batu Bara district's local election. The research method is descriptive qualitative. The data of this research are thirteen utterances/speeches of face book users in Batu Bara district's local election group account. Data were collected using the documentation method with the help of referring technique. This method is used to observe the expression of the face book users' hatred on issues related to social, cultural and political background on each candidate. Thirteen utterances analyzed are classified into assertive, directive and expressive and have illocutionary forces namely insulting, inciting and discriminating. This study indicates that hate speech can be identified linguistically.
\end{abstract}

Keywords: Hate Speech, Social Media, Speech Acts

\section{Introduction}

This research is motivated by the rise of hate speech phenomena in the life of Indonesian multicultural society both in the offline domain and in the online domain that can trigger social conflict and cause the vulnerability of the integrity of the State (Ahnaf and Suhadi, 2015).

Hate speech can be understood as any form of expression that is propagated to incite, promote or justify racial hatred, xenophobia, anti-Semitism, or other forms of hatred rooted in intolerance, including intolerance expressed by nationalism and aggressive ethnocentrism, discrimination and hostility towards minorities and migrants (Weber, 2009). In line with this, National Human Rights Commission of the Republic of Indonesia stated a somewhat similar definition that hate speech is any action and effort either directly or indirectly based on hatred on tribe, religion, religious stream, belief/faith, race, interclass, color skin, ethnicity, gender, disability, and sexual orientation which is incited towards individuals and groups to discriminate, violence, disappearance of life and /or social conflict through various means (Komisi Nasional Hak Asasi Manusia Republik Indonesia, 2016).

The Police of Republic of Indonesia cybercrime unit stated in 2015 there were 671 reports related to hate speech (Nadia, 2016). That number continues to rise in 2016 which 
amounted to 1829 cases, and until the end of 2017 reached 3325 cases (Medistiara, 2017). The number shows that there is an increase in hate speech cases on the online sphere.

To anticipate the above phenomena, the Indonesian government has actually created two laws and regulations that substantially regulate hate speech, the Criminal Code (KUHP) and the Information and Electronic Transaction Act of 2008 (Rongiyati, 2015). However, the more massive phenomena of hate speech contribute to the emergence of a Circular Letter of the Chief Police of the Republic of Indonesia No. SE / 6 / X / 2015 on the handling of hate speech. In the circular letter, as a law enforcement officer, the Indonesian National Police describes that hate speech may takes various forms such as criminal offenses, defamation, blasphemy, unpleasant acts, provocation, incitement and spreading of hoax.

The description of various forms of hate speech is a new subject for linguistic studies, especially in discourse analysis (Gagliardone, Patel \& Pohjonen, 2014) and pragmatics (Assimakopoulos, Baidar \& Millar, 2017, or speech acts related studies. However, Özarslan (2014) stated that speech act theory can be applied in analyzing hate speech. According to him, in the concept of speech acts, as proposed by Austin (1962) that when someone says something, he also does something, and may also do hate speech acts related to social and cultural context.

\section{Literature Review}

In relation to various discussions on hate speech, there are several studies that have been done based on the perspective of linguists in assessing the phenomena of hate speech. For example, research conducted by Mintonawati (2016) associated with defamation cases on Face book's social network using linguistic forensic studies involving lexical semantic analysis, grammatical semantics and analysis of illocutionary speech acts. To sum up, this research has not found specific type of illocutionary acts and forces from the data. Towsend (2014) in his research, also did not mention clearly the types of illocution of hate speech cases he discussed.

Slightly different from the two earlier studies, Virginia and Olanrewaju (2017) in their research based on speech analysis of the politician's language in Nigerian magazines and newspapers in 2012-2015 show that violence, extortion, provocation and intimidation. However, their research has not specified the type of illocutionary acts of the politicians' speeches.

Another study was Linawati's research (2017), which was specifically done in analyzing the netizen's utterances in the Online Tribunnews.com newspaper comment column. Using the theory of speech acts, she has successfully found various forms of hate speech in the Online Tribunnews.com newspaper comment column such as, humiliation, defamation, unpleasant acts, provocation and incitement and based on speech act types she found assertive, directive and commissive. Linawati's research has not found the expressive type of hate speech.

The last is a study done by Octaviani (2017). Based on her research conducted using ethnography of communication, it was found that there were forms of hate speech in the instagram account of former Governor of the Special District of Jakarta, Basuki Tjahaja Purnama. The forms of hate speech include humiliation, defamation, blasphemy, provocation, spreading hoax, and incitement. According to her, all forms of hate speech have impacts such as excommunication, discrimination, violence, hatred towards groups, and group extermination. However, this research has also not found the expressive type of hate speech. 
Based on the above explanation of hate speech from linguistic perspective, this research tries to find the classification and aims of hate speech acts contained in Face book group account related to Batu Bara district local election. This is important because the propensity for spreading hate speech is more massive when entering the period of direct election of regional heads and closely related to the discourse to seize or maintain the power (George, 2017). More is known at this time that one of the four pairs of candidates for regional head of Batu Bara district is Chinese descendant. This fact is increasingly encouraging the occurrence of hate speech in the social media such as Face book done by each supporters.

As the core study of speech acts, Searle develops and classifies speech acts into five types namely, 1. Representatives (Assertives) are those kinds which commit the speaker to the truth of the expressed proposition (asserting, concluding, etc.) 2. Commissives are those kinds which commit the speakers to some future course of action (promising, offering, threatening) 3. Directives are the attempts by the speaker to get the addressee to do something (requesting, questioning) 4. Declarations are those kinds of speech acts that change the reality in accord with the proposition of declaration (pronouncing someone guilty, etc.) 5. Expressives are speech acts that state the speaker's attitude and emotion towards the proposition (Searle, 1979). The proposed classification is based on three main principles namely, illocutionary point or the purpose of the speaker, words adjusted to the reality of the world (direction of fit), and psychological states/ sincerity condition.

Table 1. Searle's Classification of Speech Acts (adapted from Yule, 1996)

\begin{tabular}{|l|l|l|}
\hline Speech act type & Direction of fit & $\begin{array}{l}\text { S = Speaker } \\
\text { X = Situation }\end{array}$ \\
\hline Declarations & Words change the world & S causes X \\
\hline Representatives (Assertives) & Make words fit the world & S believes X \\
\hline Expressives & Make words fit the world & S feels X \\
\hline Directives & Make the world fit words & S wants X \\
\hline Commissives & Make the world fit words & S intends X \\
\hline
\end{tabular}

Searle has also proposed the idea that the realization of speech acts is influenced by four conditions, namely (1) the propositional content condition, (2) the preparatory condition, (3) the sincerity condition, and (4) the essential condition (Searle, 1969). According to him, each of these conditions can distinguish the intention of each form of speech acts. In the context of Austin's theory of speech acts, performative was applied to those utterances which are used to perform an act instead of describing it. Performative utterances thus stand in opposition to constative utterances, which are statements of facts.

\section{Research Method}

The research method used is descriptive qualitative. This research method aims to describe, summarize various conditions, various situations, or various phenomena of social reality. This study also attempted to draw the reality as a characteristic, character, trait, model, sign, or description of a particular condition, situation, or phenomenon (Bungin, 2017). The data were thirteen utterances or speech in the form of words, phrases and sentences. The data were retrieved from the utterances or speech of the members and net citizens in the Face book group account named KOMBUR- KOMBUR PILKADA BATU BARA 2018 MENUJU MASYARAKAT EKONOMI BB BERSINAR (Towards the prosperity of Batu Bara) and Face book group account named KOMBUR-KOMBUR PILKADA BATUBARA 2018 from January to May 2018. Data were collected using the documentation method. This method is 
used to observe the speech of net citizen's hatred on issues related to the social, cultural and political background of each candidate. Note technique was used to record the expression of hate speech by the net citizens (Sudaryanto, 2015).

The collected data then analyzed using referential and distributional (Sudaryanto, 2015) which then further analyzed using contextual analysis method (Rahardi, 2009). A contextual analysis is simply an analysis of a text (in whatever medium, including multi-media) that helps us not only to assess that text within the context of its historical and cultural setting, but also in terms of its textuality - or the qualities that characterize the text as a text. The context referred to in this method was the language environment. Linguistic environment might be of physical environment or nonphysical environment. In other words the context could be understood as the background knowledge shared by speakers and hearers, so the hearers could understand what the speakers meant (Leech, 1983).

\section{Findings and Discussion}

In accordance with the objectives of the study, in this section, results and discussion of research that include two things will be presented, namely: 1), classification and, 2) aims of hate speech found in Face book group account KOMBUR- KOMBUR PILKADA BATU BARA 2018 MENUJU MASYARAKAT EKONOMI BB BERSINAR (Towards the prosperity of Batu Bara) and Face book group account KOMBUR-KOMBUR PILKADA BATUBARA 2018.

\subsection{Results}

Based on the speech acts theory described earlier, three types of illocutionary acts are found. The three types of illocutionary act have their own meanings and parameters. They were found from thirteen utterances of net citizens in the Face book account. Of the thirteen utterances three illocutionary forces are found. All the findings can be seen in the following table.

Table 2. List of hate speech found in Face book group accounts KOMBUR-KOMBUR

PILKADA BATUBARA 2018 MENUJU MASYARAKAT EKONOMI BB BERSINAR (Towards the prosperity of Batu Bara) and KOMBUR-KOMBUR PILKADA BATUBARA 2018

\begin{tabular}{|r|l|l|}
\hline No. & \multicolumn{1}{|c|}{ Hate speech } & $\begin{array}{c}\text { Illocutionary } \\
\text { Acts }\end{array}$ \\
\hline 1 & $\begin{array}{l}\text { Cino dah makin merajolela di Indonesia ini di seluruh penjurunyo } \\
\text { 'Chinese are rampant all over Indonesia' }\end{array}$ & Assertive \\
\hline 2 & $\begin{array}{l}\text { Kojap lagi Indonesia pun menjadi negaro cino } \\
\text { 'In the near future Indonesia will become China' }\end{array}$ & Assertive \\
\hline 3 & $\begin{array}{l}\text { Kalau bukan punyo asing mako punya aseng } \\
\text { 'If it is not owned by Westerners, it is owned by Chinese' }\end{array}$ & Assertive \\
\hline 4 & $\begin{array}{l}\text { Kalau cino menghalalkan segala cara demi harta karna mereka } \\
\text { mati bawak harta tidak kenal riba } \\
\text { 'Chinese justify all means for the sake of wealth because they } \\
\text { bring it when they die, and they do not know usury' }\end{array}$ & Assertive \\
\hline 5 & $\begin{array}{l}\text { Saya pribadi tak ondak dan tak rela apobilo batu bara ni di } \\
\text { kuasai oleh cino. } \\
\text { 'I personally do not want Batu Bara led by Chinese' }\end{array}$ & Assertive \\
\hline 6 & $\begin{array}{l}\text { Selain dia yg di dukung itu thionghoa keturunan. } \\
\text { 'All Chinese descendants support him' }\end{array}$ & Assertive \\
\hline
\end{tabular}




\begin{tabular}{|r|l|c|}
\hline 7 & $\begin{array}{l}\text { Semua nya dari cina komunis. } \\
\text { 'Everything comes from China is communist' }\end{array}$ & Assertive \\
\hline 8 & $\begin{array}{l}\text { Dai dulu kami ondak milih pak zahir tapi chino di belakangnya } \\
\text { jadi malas odan. } \\
\text { 'Initially, we wanted to choose Pak Zahir but because there was } \\
\text { Chinese behind him, we do not want him anymore'. }\end{array}$ & Assertive \\
\hline 9 & $\begin{array}{l}\text { Ini salah satu cabup batubara yg ditunggangi anak cina sebagai } \\
\text { cawabup nya. } \\
\text { 'This is one of the regent candidates who supported by Chinese } \\
\text { as his deputy'. }\end{array}$ & Assertive \\
\hline 10 & $\begin{array}{l}\text { Ganyang CINA } \\
\text { 'Kill Chinese descendants'. }\end{array}$ & $\begin{array}{l}\text { Dukimak kau china } \\
\text { 'Fuck you Chinise' }\end{array}$ \\
\hline 12 & $\begin{array}{l}\text { Kau bukan ada hak dalam negeri kami } \\
\text { 'You have no right on our land' }\end{array}$ & Assertive \\
\hline 13 & $\begin{array}{l}\text { USIRRRR CHINA DARI INDONESIA } \\
\text { 'Throw out Chinese from Indonesia' }\end{array}$ & Directive \\
\hline
\end{tabular}

\subsection{Discussion}

Based on the analysis that has been done on both Facebook group accounts, three classifications of illocutionary acts are found, namely: assertive, directive and expressive.

\subsubsection{Assertive}

Assertive is a speech act involving the speaker on the truth of the expressed proposition. For example, states, notices, prides, complains, demands, and reports. Therefore, every act of assertive can be judged to be true. In other words, that in every assertive, speaker speaks the words to the world (belief). Then every speech from every speaker within the two Face book group accounts expresses the speakers' true belief on the information, experience and evidence they have, in relation to Chinese ethnic in Indonesia. In this case it is true that the Chinese descendants are trying to dominate Indonesia in any way. Based on the truth as believed by each speakers, the assertive found in this study can be described as follows.

Table 3. Illocutionary assertive acts found in KOMBUR-KOMBUR PILKADA BATUBARA 2018 MENUJU MASYARAKAT EKONOMI BB BERSINAR (Towards the prosperity of Batu Bara) and KOMBUR-KOMBUR PILKADA BATUBARA 2018

\begin{tabular}{|c|c|}
\hline \multicolumn{2}{|r|}{ Illocutionary Assertive Act } \\
\hline Propositional content & $\begin{array}{l}\text { truth of the information, experience and evidence that } \\
\text { Chinese descendants try to dominate Indonesia (Pc) }\end{array}$ \\
\hline \multirow[t]{2}{*}{ Preparatory } & 1. Speaker (S) has facts, reasons, evidences on Pc \\
\hline & 2. Hearer has no clear reasons on $\mathrm{Pc}$ \\
\hline Sincerity & Speaker believes Pc \\
\hline Essential & Pc shows that the information is true \\
\hline
\end{tabular}

There are two sub types of assertive found in this case, namely statement and predicting. 


\section{a. Statement}

This sub type indicates the speaker's belief in stating something. There are two aims of this sub type, i.e. to state and to inform. The parameter of this category is when the speaker speaks, the speaker states that the Proposition is: i). stating that there is information, ii) experience and iii) evidence that he believes that Chinese is an ethnic who is trying to dominate Indonesia in any way. The explanation of this sub-type can be seen in (1) Cino dah makin merajolela di Indonesia ini di seluruh penjurunyo [...] (HS.01) 'Chinese are rampant all over Indonesia'. The utterance (1) is a statement of assertive sub type.

Through the utterance (1) speaker tries to declare that Chinese in Indonesia are trying to dominate Indonesia. It seems that this prejudice arose after the Presidential election of Indonesia in 2014. It continued after the act to protect Islam against defamation I, II, and III, which asked the government to punish Basuki Tjahaja Purnama who had defamed Islam. Meanwhile, the news of a large wave of foreign workers from the People's Republic of China (PRC) increasingly leads to situations and sentiments between ethnics and religions in Indonesia. One way to think about the speech acts being performed via utterances is to assume that in underlying of every utterance $(U)$ there is a clause, containing a performative verb (Vp) which makes the illocutionary force explicit (Austin, 1962). This is known as performative hypothesis and the basic format of the underlying clause is 'I (hereby) Vp you (that) U' (Yule, 1996). Applying paraphrase technique as proposed by Sudaryanto (2015) on hate speech (1) the true aim of statement of assertive sub type can be exercised, "I hereby \{state/ inform\} you that Chinese are rampant all over Indonesia".

\section{b. Predicting}

This sub-type predicts what will happen in the future based on the speaker's belief. The parameter of this sub type is when speaker utters the speech, the speaker predicts the Proposition ( $\mathrm{Pc}$ ): i). Predicting that something will happen as evidence that the information, experience and evidence of ethnic Chinese ambition that he has is true. Explanation of this sub-type can be seen in (2) Kojap lagi Indonesia pun menjadi Negara Cina [...] (HS.02). In the near future Indonesia will become China [...]. The sub-type truth can be tested by the performative hypothesis and paraphrase technique as described earlier. Consider the following illustration: (2) I hereby \{predict that in the near future Indonesia will become China [...]. This sub-type truth test is also carried out using changing and extending techniques. Look at the following illustrations: (2a) I hereby predict that Indonesia will become China [...], (2b) I hereby predict that it seems Indonesia will become China [...], (2c) My prediction might be that Indonesia will become China [...].

Based on the above paraphrase technique, it can be said that the utterance (2) is an assertive of predicting sub-type, the speaker intended to predict what would happen if the Chinese and the foreign workers from China had succeeded in carrying out Indonesia.

\subsubsection{Directive}

Directive is a speech act intended by the speaker to make the hearer does something. For example, ordering, begging, requesting, suggesting, and advising. Therefore, the propositional content of the directive speech act is a future act of the hearer. Based on this, it is understood that in each directive speech, the speaker seeks to make the world fit words. Related to that, then every directive speech within the two Face book accounts express the actions of hearers in the future that is a persuasion to murder Chinese descendants and an order to expel them from Indonesia. 
Table 4. Illocutionary Directive acts found in Face book group accounts of KOMBUR-KOMBUR PILKADA BATUBARA 2018 MENUJU MASYARAKAT EKONOMI BB BERSINAR (Towards the prosperity of Batu Bara) and KOMBUR-KOMBUR PILKADA BATUBARA 2018

\begin{tabular}{|l|l|}
\hline \multicolumn{2}{|c|}{ Illocutionary Directive Acts } \\
\hline Propositional content & $\begin{array}{l}\text { An action }(\mathrm{A}) \text { that will be carried out by the hearer in the } \\
\text { future }\end{array}$ \\
\hline Preparatory & $\begin{array}{l}\text { 1. The hearer }(\mathrm{H}) \text { can do an action (A), and the speaker } \\
\text { believes that the hearer is able to do an action }(\mathrm{A})\end{array}$ \\
\cline { 2 - 2 } & $\begin{array}{l}\text { 2. It is not clear to the speaker and the hearer that the } \\
\text { hearer is able to do an action as directed by the speaker }\end{array}$ \\
\hline Sincerity & The speaker wanted the hearer to do an action (A) \\
\hline Essential & To persuade the hearer to do an action $(\mathrm{A})$ \\
\hline
\end{tabular}

Based on the description above, one sub type of directive is found namely to persuade. This sub-type is based on the speaker's intention for the hearer to do something in the future. The parameter is when telling the utterance, the speaker persuades the hearer to perform an action, the speaker expresses: i). a wish that the hearer does an action (A), ii) that action $(A)$ is the speaker's wish. An explanation of this sub-type can be seen as follows, (3) Ganyang CHINA. (HS.03) 'Kill Chinese descendants'. Utterance (3) is a persuasion subtype of illocutionary directive acts. Through utterance (3) speaker tries to persuade hearer to kill Chinese descendants. To examine the truth of this sub type, the formula "S verb (O) that $X$ " or "S verb O to Y" is used (Yule, 1996). Consider the following: (3) I persuade you to kill Chinese descendants. After using paraphrase technique, it can be said that utterance (3) is a persuasion sub-type of illocutionary directive acts, in which the speaker persuades the hearer to kill Chinese descendants.

\subsubsection{Expressive}

Expressive is a speech act that expresses the speaker's psychological attitude to a situation. It could be an expression of gratitude, joy, hatred, anger, forgiveness, blame, praise, condolence, and so on. Yule (1996) explains that when speakers use illocutionary expressive acts they attempt to fit words to the world. Based on this, it can be understood that every illocutionary expressive acts found in this study show resentment of speakers to Chinese descendants based on a state of experience, information, and evidence that already possessed by speakers.

Table 5. Illocutionary Expressive acts found in Face book group accounts of KOMBUR-

KOMBUR PILKADA BATUBARA 2018 MENUJU MASYARAKAT EKONOMI BB BERSINAR

(Towards the prosperity of Batu Bara) and KOMBUR-KOMBUR PILKADA BATUBARA 2018

\begin{tabular}{|l|l|}
\hline \multicolumn{2}{|l|}{ Illocutionary Expressive acts } \\
\hline Propositional coentent & $\begin{array}{l}\text { An event has been experienced and influenced the } \\
\text { speaker's attitude towards Chinese descendants. }\end{array}$ \\
\hline Preparatory & \begin{tabular}{l} 
1. Speaker has fact, reason and evidence on Pc. \\
\hline Sincerity
\end{tabular} \\
\hline Essential & - \\
\hline
\end{tabular}

Based on the description above, one sub type of expressive is found namely offensive. This sub-type is based on the expression of the speaker's hatred for Chinese descendants based on a state of experience, information, and evidence that the speaker has. The parameter is when the utterance is spoken, speaker insults hearer by expressing: i) speakers' 
dislike toward Chinese descendants, ii) and the speaker's hatred on all Chinese activities. An explanation is as follows: (4) Pukimak kau China (HS.04) 'Fuck you....'. Utterance (4) is an offensive sub-type of illocutionary expressive act. Through utterance (4) speaker shows his dislike and hatred towards Chinese descendants.

\section{Conclusion}

Based on the results of research and discussion, it can be concluded that hate speeches found in Face book group accounts KOMBUR- KOMBUR PILKADA BATU BARA 2018 MENUJU MASYARAKAT EKONOMI BB BERSINAR (Towards the prosperity of Batu Bara) and KOMBURKOMBUR PILKADA BATUBARA 2018 are classified into assertive, directive and expressive. In addition, the thirteen utterances analyzed have illocutionary forces that are insulting, inciting and discriminating, especially on Chinese descendants. This happened because one candidate for Batu Bara local election is Chinese descendant.

This study concludes that legal cases on hate speech can be interpreted and solved linguistically provided that fairness and social justice are the ends to be achieved.

\section{Acknowledgements}

The authors gratefully acknowledge that the present research is supported by Ministry of Research and Technology and Higher Education Republic of Indonesia. The support is under research grant DRPM of year 2019 contract number: 11/E1/KP PTNBH/2019.

\section{References}

Ahnaf, M. Iqbal \& Suhadi. (2015). Isu-Isu Kunci Ujaran Kebencian (Hate Speech): Implikasinya Terhadap Gerakan Sosial Membangun Toleransi. Harmoni: Jurnal Multikultur Multireligius. 3 (13), pp.153-154.

Assimakopoulos, Stavros, Baider, Fabienne H, \& Millar, Sharon. (2017). Online Hate Speech in the European Union: A Discourse Analytic Perspective. Switzerland: Springer.

Austin, J. L. (1962). How to Do Things with Words. London: Cambridge University Press.

Bungin, Burhan. (2007). Penelitian Kualitatif: Komunikasi, Ekonomi, Kebijakan Publik, dan IImu Sosial Lainnya. Jakarta: Kencana.

Gagliardone, Ignio, Patel, Alisha \& Pohjonen, Matti. (2014). Mapping and Analysing Hate Speech Online: Opportunities and Challenges for Ethiopia. Oxford: OUP

George, Cherian. (2017). Pelintiran kebencian: Rekayasa Ketersinggungan Agama Dan Ancamannya Bagi Demokrasi. PUSAD Yayasan Paramadina dan IIS UGM. Jakarta.

Kepolisian Negara Republik Indonesia. (2015). Surat Edaran Kepala Kepolisian Negara Republik Indonesia Nomor: SE/6/X/2015 tentang Penanganan Ujaran Kebencian (Hate Speech). Jakarta.

Komisi Nasional Hak Asasi Manusia Republik Indonesia. (2016). Buku Saku Penanganan Ujaran Kebencian (Hate Speech). Jakarta.

Leech, Geofrey. (1983). Priciples of Pragmatics. New York: Longman.

Medistiara, Yulid. (2017). 'Selama-2017-polri-tangani-3325-kasus-ujaran-kebencian', Detik News, 29 Desember, viewed 23 Juli 2018, < https://news.detik.com/berita/d3790973/selama-2017-polri-tangani-3325-kasus-ujaran-kebencian>.

Mintonawati. (2016). 'Pencemaran Nama Baik: Kajian Linguistik Forensik', PARAMASASTRA, $3(2)$, pp. 27-37.

Nadia, Ambaraie. (2017) 'Konten berisi ujaran kebencian paling banyak diadukan', Kompas.Com, 26 March, viewed 23 Juli 2018, 
https://nasional.kompas.com/read/2017/03/26/08465611/2016.konten.berisi.ujaran .kebencian.paling.banyak.diadukan.ke.polisi.

Octaviani, Aulia. (2017). 'Ungkapan Kebencian Pada Tuturan Heaters Di Akun Instagram BasukiBTP Dan Relevansinya Terhadap Pembelajaran Bahasa Indonesia Di SMA', eprints.ums.ac.id, 03 August, viewed 23 Juli 2018, http://eprints.ums.ac.id/id/eprints/54308.

Özarslan, Zeynep. (2014). Introducing Two New Terms into The Literature of Hate Speech: "Hate Discourse" And "Hate Speech Act" Application of "Speech Act Theory" Into Hate Speech Studies in The Era of Web 2.0. Haziran. (20), pp.53-75.

Rahardi, Kunjana. (2009). Sosiopragmatik. Jakarta: Erlangga.

Rongiyati, Sulasi. (2015). Surat Edaran Kapolri Tentang Ujaran Kebencian: Menjaga Kebebasan Berpendapat Dan Harmonisasi Kemajemukan. Info Singkat Hukum, Vol.II, No.21.pp.1-5

Searle, John R. (1979). Expression and Meaning: Studies in the Theory of Speech Act. Cambridge: Cambridge University Press.

Searle, John R. (1969). Speech Acts an Essay in The Philosophy of Language. Cambridge: Cambridge University Press.

Sudaryanto. (2015). Metode dan Aneka Teknik Analisis Bahasa Pengantar Penelitian Wahana Kebudayaan secara Linguistis. Yokyakarta: Sanata Dharma University Press.

Townsend, Emma. (2014). Hate Speech or Genocidal Discourse? An Examination of AntiRoma Sentiment in Contemporary Europe. Portal. 11 (1). 1-23

Virginia, Okafor C \& Olarenwaju, Alabit Taofeek. (2017). 'A Speech Act Analysis of Hate Speeches in the 2015 General Election Campaign in Nigeria', IMPACT: Internasional Journal of Research In Humanities, Arts and Literature. 5 (6). 61-72.

Weber, Anne. (2009). Manual on Hate Speech. France: Council of Europe.

Yule, George. (1996). Pragmatic. Oxford: Oxford University Press. 